\title{
CRYPTOCURRENCY AND DIGITAL MONEY IN ISLAMIC LAW: Is it Legal?
}

\author{
Husnul Fatarib ${ }^{1,}$ Meirison $^{2}$ \\ ${ }^{1}$ Institut Agama Islam Negeri Metro Lampung, ${ }^{2}$ Universitas Islam Negeri \\ Imam Bonjol Padang, Indonesia \\ Email: husnul.fatarib@yahoo.com
}

\section{Abstract}

Cryptocurrency is a digital currency spread in peer-to-peer network all over the world. This network has a big accounting book called Blockchain which can be accessed by public. This article is doctrinal legal research with conceptual research. This article reviews digital money based on Jalbu Masalah wa Dar al-Mafasid accompanied by the implication of Saddu az-Zariah. The results show that Islamic law acknowledges the currency issued by the government. The existence of a country is a form of protection to the money owners from the acts of fraud in finance. Bitcoin and digital money are not included in the criteria mentioned in Islamic economy law because of it contains obscurity (jahalah), high speculation element, and can harm individual as well as the country. Bitcoin has no clear source, authentic balance, and it only has moral assurance.

Mata uang kripto adalah mata uang digital yang tersebar dalam jaringan peerto-peer di seluruh dunia. Jaringan ini memiliki sebuah buku akuntansi besar bernama Blockchain yang dapat diakses oleh publik. Artikel ini merupakan penelitian bukum doctrinal dengan pendekatan konseptual. Artikel ini melakukan kajian terhadap uang digital berdasarkan Jalbu Masalah wa Dar al-Mafasidsertai implikasi Saddu az-Zariah. Hasilpenelitian ini menunjukkan bahwa hukum Islam mengakui keberadaan mata uang yang dicetak oleh pemerintah. Keberadaan negara merupakan wujud perlindungan kepada pemilik uang dari tindakan penipuan dan kecurangan dalam bidang finansial. Bitcoin dan uang digital tidak termasuk dalam kriteria yang disebutkan dalam hukum ekonomi Islam. Karena mengandung ketidakjelasan (jahalab), unsur spekulasi yang tinggi serta dapat merugikan individu dan negara. Bitcoin ini tidak mempunyai sumber yang jelas, saldo yang hakiki, dan hanya ada jaminan secara moril.

Keywords: cryptocurrency, currency, Islamic economy law. 


\section{Introduction}

Cryptography: The word of cryptography derives from Greek which is translated as 'hidden writing.' It has a literal meaning of 'the science of secret writing. Crypto is 'secret or hidden', while graphy is 'writing.' Thus, cryptography is a secret writing or secret signature, a digital signature. ${ }^{3}$ Scientifically, cryptography is the meeting point among science, Mathematics, Computer Science, and Electrical Engineering. Computational encryption algorithms are designed with the assumption that they are anti-hacking because the purpose of using cryptography is for security. ${ }^{4}$ The use of this application has long been used in ATMs, computer passwords, and electronic commerce. Now cryptography is used as the secret key for Bitcoin virtual money in Blockchain technology. Cryptography works on the basis of a specially crafted encryption algorithm that is used to validate and verify transactions. ${ }^{5}$

The Blockchain technology was developed in 2009 by Satoshi Nakamoto who is a developer of Bitcoin called digital currency. Bitcoin is the blockchain, a complex and evolving technology with tremendous potential and less risk whose main promise is a world without intermediaries. ${ }^{6}$ However, its identity is still disguised today. In early 2018 the price reached US\$11,110. Questions arise about trading cryptocurrency of digital currencies and the most popular is Bitcoin, which starts at 2 cents and has reached thousands of USD per coin, and the price continues to increase according to supply and demand. However, after that the value of bitcoin dropped 80 percent from its highest point. Likewise, the ethereum, whose price fell from a range of US $\$ 1,400$ dollars to USD102 in May 2018. ${ }^{7}$

Bitcoin value is unstable and vulnerable to various kinds of influences that can harm its owner. Bitcoin is like a game that takes up a lot of time and

1 Kenneth H. Rosen, Douglas R. Shier, and Wayne Goddard, eds., Handbook of Discrete and Combinatorial Mathematics, Second edition (Boca Raton: CRC Press, Taylor \& Francis Group, 2018), h.199.

2 Willem Conradie and Valentin Goranko, Logic and Discrete Mathematics: A Concise Introduction (Chichester, West Sussex, UK; Hoboken, NJ, USA: John Wiley \& Sons Inc, 2015),h. 272.

3 Asep Zaenal Ausop and Elsa Silvia Nur Aulia, "Teknologi Cryptocurrency Bitcoin Untuk Investasi Dan Transaksi Bisnis Menurut Syariat Islam,” Jurnal Sosioteknologi 17, no. Vol.17, No1, April 2018 (April 2018): 19, http://dx.doi.org/10.5614\%2Fsostek.itbj.2018.17.1.8.

4 Ausop and Aulia.

5 Ausop and Aulia.

6 Dr. S. T. Bhosale Dr. S. T. Bhosale, "BLOCKCHAIN IN HIGHEREDUCATION INSTITUTIONS," International Journal of Advance and Innovative Research 6, no. 3 (September 2019): 124-27.

7 Astrid Dwijayanti Astrid Dwijayanti, "Pasar Mata Uang Kripto Alami Tren Penurunan, Berbeda Dengan Indonesia Yang Pertahankan Stabilitas Harganya," Commerce, Finroll.Com (blog), December 3, 2018. 
full of speculation. Can computer games in the form of software be considered money that has intrinsic value? Its origin and management are unclear and full of uncertainty which is contained with gharar (fraud).

This article is an attempt to find answers to the legal status of digital assets in terms of the definition of assets in Islam. Is the computer software that can be converted into assets equal to the status of fiat money? To get answers about the status of digital assets, the author carefully examines what digital asset is, why it is created, and how the system works. After discussing the nature of crypto money, you will find the position of this money in the Islamic Shari>ah through the Qur'an and Hadith texts.

In the writing process, studying books on foreign monetary policy was carried out, such as the book The Theft of Nation compiled by Ahamed Kameel Mydin Meera, which discusses the intrinsic value of money owned by the dinar, as well as the loss of gold support for USD as the country>s member foreign exchange reserves, as agreed in the Bretton Wood agreement. ${ }^{8}$ The writer also studied the book al-Ahkam Sultaniyah written by al-Mawardi which defines money that must be printed and its value is guaranteed by the government. Therefore, money must have a clear source that is recognized and used by many people and must not be deliberately reduced in value. This deliberate reduction in value is part of the act of damage on earth that is prohibited by Allah SWT.' The writer conducted a literature study of books or writings related to other discussion titles such as "The bitcoin standard: the decentralized alternative to central banking" by Ammous, which discusses alternative shifts from conventional banks to digital banks as well as problems of digital money that is no longer under the control of world banks which can solve the problems of banking institutions and it is a very good solution. The problems of large transactions are resolved in minutes. ${ }^{10}$ The writer also refers to the article written by Asep Zaenal Ausop and Elsa Silvia Nur Aulia in the Sociotechnology Journal entitled Bitcoin Cryptocurrency Technology for investment and Business Transactions according to Islamic Shari'ah Vol.17, No.1, April 2018. This article gives an explanation of the meaning of Bitcoin and an overview of Bitcoin virtual technology in the working pattern of

8 Ahamed Kameel Mydin Meera, The Theft of Nations: Returning to Gold (Subang Jaya, Selangor Darul Ehsan, Malaysia: Pelanduk Publications, 2004), p.220.

9 Alī ibn Muḥammad Māwardī and Aḥmad Mubārak Baghdādī, Kitāb Al-Aḥkām al-Sulțānīyah Wa-alWilāyat al-Dinìyah, al-Ṭabah 1 (al-Manșūrah [Egypt] : al-Kuwayt: Dār al-Wafā ; Maktabat Dār Ibn Quțaybah, 1989), 223.

10 Saifedean Ammous, The Bitcoin Standard: The Decentralized Alternative to Central Banking (Hoboken, New Jersey: Wiley, 2018), 12. 
Blockchain technology and the legal position of using Bitcoin as an investment and transaction instrument. Another article that is used as a reference is MiningTrading Cyriyptocurrency in Islamic Law written by Muhammad Fuad Zain in the journal al-Manahij Vol. XII No.1, June 2018. ${ }^{11}$ It describes the mining process to get Bitcoin using a specific computer with certain results according to the type of device used. ${ }^{12}$ The novelty of this discussion is the focus on the element of money in Islam which is related to the role of gold as a supporter of the intrinsic value of the money, which is only officially printed by the government according to Islamic law and cannot be released to anyone who will cause chaos and instability in the economy. Irresponsible parties will do a lot of chaos and problem. ${ }^{13}$

\section{Research Methods}

The writer explains this article using a descriptive method by deduction and induction, understanding the problems through the texts of the al-Qur'an and Hadith and the ijtihad (reasoning) of the ulama (scholars) ${ }^{14}$ to analyze the nature of digital money or Bitcoin. ${ }^{15}$ In the Quran and hadith, it is indicated that the intrinsic value and equality of the value of money and goods depending on supply and demand. On the contrary, it can be seen in the practice of the economy during Khalifah period (caliphate) which also allowed the use of fiat money but under state supervision and in fact it was still supported by gold. ${ }^{16} \mathrm{On}$ the other hand, based on the facts in the practice of printing money, trade transactions are carried out by economic practitioners during the Islamic Sharia period applied, so the writer tries to make a general explanation of money and its benefits for Muslims and its relation to production factors. ${ }^{17}$ Using the theory proposed by

11 Muhammad Fuad Zain, "Mining-Trading Cryptocurrency Dalam Hukum Islam," Al-Manahij: Jurnal Kajian Hukum Islam 12, no. 1 (June 22, 2018): 119-32, https://doi.org/10.24090/mnh.v12i1.1303.

12 Zain.

13 A.M. Māwardī and A.M. Baghdādī, Kitab Abkam Sultaniyah Wa Wilayah Ad-Diniyah (ار الوفاء $1989, \vdots)$, p.181

14 Sa'ad al-Syatari Sa'ad al-Syatari, Al-Takbrij Baina al-Usbul Wa al-Furu (Kairo: Dar al-Hadits, 1989),h. 91.

15 Muhammad Bahits, Ikrar Indama Asbaha Waziran (Dar Sibawaihi Li Taba' wa Nasyr, 2018),h.98

16 Al̄̄ ibn Muḥammad Māwardī and Aḥmad Mubārak Baghdādī, Kitäb Al-Aḥkām al-Sulțānìyah Wa-al-Wilāyat al-Dinìyah, al-Ṭabah 1 (al-Manșūrah [Egypt] : al-Kuwayt: Dār al-Wafā ; Maktabat Dār Ibn Quțaybah, 1989), p.181.

17 Revi Fitriani, "Pemikiran Ekonomi Islam Ibnu Khaldun Islamic Economic Thought Of Ibnu Khaldun," no. 2 (2019): 15. 
Jalbu al-Masalih wa Daf'u al-Madharat, the writer analyzes the legal status of bitcoin as money, its intrinsic value and the possible criminal acts that will happen with the rule of sad 'az-zariah. ${ }^{18}$

\section{Discussion}

Before discussing the basic law and use of crypto money, the writer should explain the nature of digital money or Bitcoin along with its criteria and characteristics and compare it with money according to Islamic law and paper money that is currently valid without the support of gold. Cryptocurrency and Bitcoin are ${ }^{19}$ :

Cryptocurrency and bitcoin are like real money but cannot be seen, hold, or spent it directly. It is an encrypted digital currency, which is very accurate. Bitcoin is one of the hundreds and possibly thousands of cryptocurrencies on the internet. Cryptocurrencies are digital currencies that use cryptographic technology for security that makes them non-counterfeitable. The price value of pure cryptocurrency is determined by market forces, namely the supply and demand of users of this technology. Apart from bitcoin, there are various cryptocurrencies that are taken into account, including Etherium, IOTA, Bitcoin cash, Litecoin, Ripple, Dogecoin and many others. ${ }^{20}$

Cryptocurrencies are created through peer-to-peer transactions called nodes that have cryptographic codes. Bitcoin, for example, consists of a group of communities/networks that make transactions and everyone has an interconnected record of every transaction made. Each transaction is accompanied by its own encryption code which will be approved later. Once approved, the transaction code will be extracted into block units. Each block joins into a block chain (blockchain). Approval is the basic concept for this crypto technology, if a transaction is not approved, the transaction can be ignored. This characteristic of cryptocurrency transactions is one-way and the senders are almost always anonymous. ${ }^{21}$

18 Majid Salim Drausyah, Saddu Zarai’ fi Jaraim al-Qatl: Dirasah Muqaranah, 2008, p.114

19 Luigi Wewege, The Digital Banking Revolution: How Financial Technology Companies Are Rapidly Transforming Retail Banking. (Cork: BookBaby, 2017), http://public.eblib.com/choice/publicfullrecord.aspx?p=4801300.

20 Zain, "Mining-Trading Cryptocurrency Dalam Hukum ISLAM."

21 Zain. 
Figure 1. Mining Cryptocurrency Sistem ${ }^{22}$

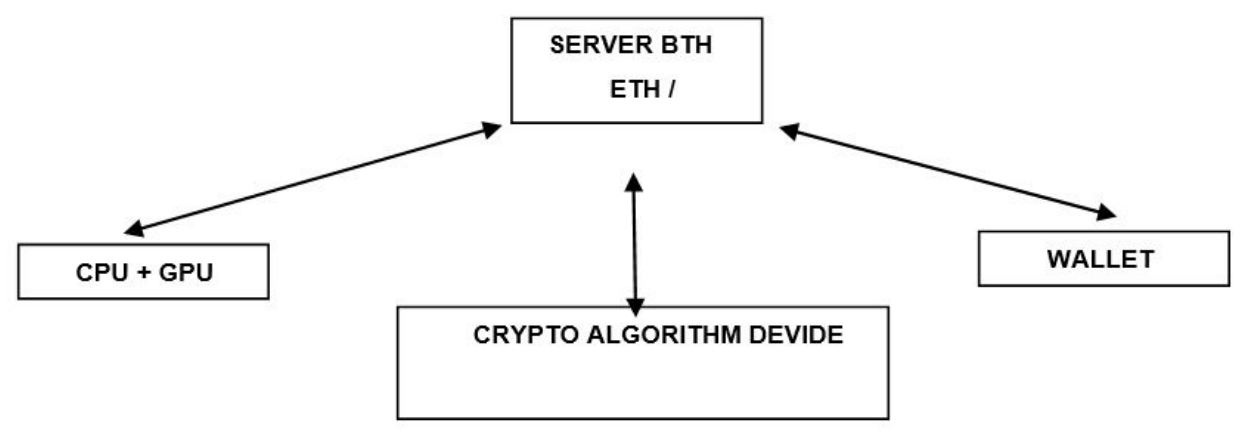

Source: Based on Processed Primary Data

The use of cryptocurrencies has become very popular in countries such as Japan, Sweden instead of paper money which requires the usual printing and a lot of effort to disseminate. The world has turned to the digital era, money has been printed in digital form or in electronic form which is stored on a computer, but it is protected in a complicated way and cannot be counterfeited just like physical money. Like physical one, digital money also has types, such as Dollars, Pounds, Riyal, Yen and others and has many types, the most famous are Bitcoin, Lightcoin, Ethereum and others. Most of them are not protected by any money, be it physical money or gold and silver. There are only currency replacement agreements made by certain parties related to this electronic money. The parties related to this electronic money promise to buy it and exchange it for real money or objects. Here lies the difference between guarantees and responsibilities and the agreement can be sold (transformed). ${ }^{23}$

The difference between this electronic money with paper money and coins is that the later originate from the central bank of a country that is recognized internationally. While electronic money is issued by known and unknown parties. Electronic money is not subject to international laws and regulations, therefore many smugglers use this electronic money. It is done because they can make transactions outside the bank and are difficult to track and monitor. The value of this currency is volatile and varies over a short period of time drastically. This

$22^{22}$ Zain.

$23{ }^{23}$ Malcolm Campbell-Verduyn, ed., Bitcoin and beyond: Cryptocurrencies, Blockechains and Global Governance, RIPE Series in Global Political Economy (London ; New York: Routledge, Taylor \& Francis Group, 2018), p.29 
electronic money is much influenced by the market and some of it is deliberately influenced by its value. Meanwhile, the value of paper money is influenced by the economic strength of a country and much more stable than electronic money. ${ }^{24}$ This electronic money is basically just computer software which is turned into an object of value which means computer software as money.

Many researchers only discuss the value of currency. They make the valuable currency as a juridical basis and allow transactions with currencies that already have that value criterion. Then riba (usury) happens, and zakat is required for transactions of electronic money for two opposing elements. Some researchers say ${ }^{25}$, "the price volatility it causes is drastically similar to the gambling which is forbidden by the syara' (Islamic law). Some researchers also say that digital money is not impossible to be faked in a certain form, therefore it is forbidden to be used as a transaction tool. Meanwhile, other researchers argue that digital money is easier to use as a medium for smuggling and money laundering and other international crimes. ${ }^{26}$ Therefore, digital money is prohibited from being used as a medium of transactions. These causes can affect the law on digital money even though it cannot be used as an Illat (basic nature) that influences the law.

Some ulema (Islamic scholars) do not comment on this digital money law and some allow it. ${ }^{27}$ Digital money is seen as a valuable transaction tool and it is the same as coins and paper which was hinted at by Khalifah/Caliph Umar bin Khatab who legalized the use of camel skin as money. However, he was worried that the camel would become extinct if the skin was continuously used as a material for making money. They also argue that if this electronic money is processed in accordance with paper money recognized by the international community, its use is under the rule of law, so its use is considered legal. ${ }^{28}$ Especially if this digital money is guaranteed with gold or other concrete assets, then its use is allowed. However, these experts have never voiced a guarantee of money with gold and its impact on the world economy which has been a problem in establishing the law. ${ }^{29}$

$24{ }^{24}$ Pedro Franco, Understanding Bitcoin: Cryptography, Engineering and Economics, Wiley Finance Series (Chichester, West Sussex, United Kingdom: Wiley, 2015), p.22

25 Ibrahim Bassam Zubaidi and Adam Abdullah, "Developing a Digital Currency from an Islamic Perspective: Case of Blockchain Technology," International Business Research 10, no. 11 (September 29, 2017): 79, https://doi.org/10.5539/ibr.v10n11p79.

26 Malte Moser, Rainer Bohme, and Dominic Breuker, "An Inquiry into Money Laundering Tools in the Bitcoin Ecosystem," in 2013 APWG ECrime Researchers Summit (2013 eCrime Researchers Summit (eCRS), San Francisco, CA, USA: IEEE, 2013), 1-14, https://doi.org/10.1109/eCRS.2013.6805780.

27 zain, "Mining-Trading Cryptocurrency Dalam Hukum IslaM."

28 Yingiie Zhao, "Cryptocurrency Brings New Battles into the Currency Market," 2015, https://doi. org/10.2313/net-2015-03-1_13.

29 islamic Business School, College Of Business, Universiti Utara Malaysia, Malaysia Et Al., "Cryptocurrency 
Before discussing digital money, whether the money is considered a valuable asset or not until it can be understood that the function of gold support and the legal impact of muammalah (social interactions) of digital money. Pay attention to the basics of creation and the origin of digital money. The money is made without any supporters. It is just numbers and electronic forms that are written and described and programmed by programmers which cannot be seen and felt in reality. Digital money does not have significant costs to create it, apart from the cost of depreciation of goods, electricity and time spent. It is not like gold which needs to be mined and removed from the bowels of the earth which carries a lot of risks and costs. In other words, it can be said that this type of currency was made with very minimal capital and without hard work that did not come from a concrete object. Paper money could no longer be used as a reference after they were released from the gold undertaken by the United States in 1971 known as the "Nixon shock" ${ }^{30}$

The Vietnam War had a major impact on the US economy. President Nixon was provoked to increase state spending again in order to increase economic activity. The US and many countries around the world at that time were bound by the Bretton Woods agreement. Ponsterling and USD can be used as the country's foreign exchange reserves as a substitute for gold, provided that the UK and US will control the amounts of ponds and dollars according to the gold reserves they have, this means that the gold standard is still in effect which means that the money at that time is not printed arbitrarily. ${ }^{31}$ Nixon was tricked into making a fake check or in other words, fake money. What happened then? French General Charles DeGaulle saw this as a bad thing. He ordered the French government to exchange USD reserves for gold immediately in 1967. Many followed DeGaulle's footsteps, exchanging their dollar reserves for gold, the dollar rushed, as happened in the 1930s. ${ }^{32}$

Finally, Nixon closed the door unilaterally to exchange dollars for gold in $1971 .^{33}$ The United States expenditure is high to finance various wars, ranging from

Framework Diagnostics From Islamic Finance Perspective: A New Insight Of Bitcoin System Transaction," International Journal Of Management Science And Business Administration 4, no. 1 (2017): 19-28, https://doi.org/10.18775/ijmsba.1849-5664-5419.2014.41.1003.

30 Ahamed Kameel Mydin Meera, The Theft of Nations: Returning to Gold (Subang Jaya, Selangor

Darul Ehsan, Malaysia: Pelanduk Publications, 2004), p.168

31 Ahamed Kameel Mydin Meera, p.221

32 Alice Teichova, G Kurgan-van Hentenryk, and Dieter Ziegler, Banking, Trade and Industry: Europe, America and Asia from the Thirteenth to the Twentieth Century (Cambridge: Cambridge University Press, 2011), p.131

33 Douglas A. Irwin, "The Nixon Shock after Forty Years: The Import Surcharge Revisited," World 
the cold war, the Arab-Israeli war (from behind) and other wars in South America, the deficit increased. So, in the next 10 years the price of gold skyrocketed from $\$ 35 / \mathrm{oz}$ to $\$ 875 / \mathrm{oz}$ before falling again to the range of $\$ 260$ - $\$ 300 / \mathrm{oz} .^{34}$

Since the gold standard was abandoned, since 1971 the amount of printed money and credits/debt increased rapidly and non-gold reserves increased too. Until 1998 the amount reached US\$1.4 trillion from less than US\$ 100 billion in 1971. Most of these reserves were in the form of USD and US (treasury) bonds. In 2004 Japan and China were the holders of bonds issued by the US government of approximately US\$2.2 trillion. The portion of gold in many central banks is small. In the cases of Mississippi and John Law, the bubble erupted about 6 years after the start of the paper money printing program. ${ }^{35}$ Likewise with the Weimar hyperinflation that happened for 1918-1923, only 6 years. What about the dollar today, since 1971 has not the financial system no longer used gold. ${ }^{36}$ Since the abandonment of the gold standard (the Bretton Woods agreement), economic crises have become more frequent in the world. High inflation financial crisis 1973-1980 in USA, in Argentina (1980-82, 1995), Chile (1981-1983), Brazil (1994-1996), Mexico (1994), Asia (1997-1998), Japan (1992), Russia (1998), the High Tech crisis in the Nasdaq and last 2008 crisis happened everywhere. ${ }^{37}$

With the opening of trade between nations and the use of the US Dollar as international money, the crisis can be postponed. The profound illusion that the dollar is a hard currency means the end of the fake money can be delayed. How did it end? just keep that information for academics and history. What is important is how to save yourself from the evil plans of bandits, rulers and politicians by saving assets in the form of real assets, property, land or gold. ${ }^{38}$

Prior to 1971 in accordance with the Bretton Wood agreement, paper currency was backed up with gold in a suitable proportion which meant that the printing

Trade Review 12, no. 1 (January 2013): 29-56, https://doi.org/10.1017/S1474745612000444.

34 Mahmud Yazbak, Haifa in the Late Ottoman Period, 1864-1914 : A Muslim Town in Transition, First, vol. 2, 1 vols. (Leiden, Netherlands: Brill, 1998); Abdolreza Yazdani-Chamzini et al., "Forecasting Gold Price Changes By Using Adaptive Network Fuzzy Inference System," Journal of Business Economics and Management 13, no. 5 (October 4, 2012): 994-1010, https://doi.org/10.3846/16111699.2012.683808

35 Philippe Beaugrand, Henry Thornton, Un Précurseur de J.M. Keynes, Travaux et Recherches de

l'Université de Droit, d'économie et de Sciences Sociales de Paris, no 9-11 (Paris: Presses universitaires de France, 1981), p.115

36 Dana Meachen Rau, The History of Money, Money and Banks (Milwaukee, WI: Weekly Reader Early Learning Library, 2006), p.115

37 "Paradoks Fatwa Dewan Syari'ah Nasional Majelis Ulama Indonesia Dalam Regulasi Hukum Perbankan Syari'ah Dan Alternatif Solusinya", Al-Ahkam, no. 1 (2017): 2. .

38 Moser, Bohme, and Breuker, "An Inquiry into Money Laundering Tools in the Bitcoin Ecosystem." 
of money could not be carried out without reference to existing gold reserves. ${ }^{39}$ This gold support is a requirement so that the USD and the pound sterling can be used as foreign exchange by the countries that are in the agreement which is ultimately violated by the United States itself. This was like the construction of a mega project carried out by Soekarno, the confrontation with Malaysia, the PRRI rebellion against the central government; moreover money was printed out of control. ${ }^{40}$ Hyperinflation was inevitable due to the continuous printing of money, so that on December 13, 1965 the government cut the value of money from IDR 1000 to IDR 1 . This policy dealt a major blow to national banks, especially those that had deposited additional capital due to a drastic decline in value in the blink of an eye $\mathrm{e}^{41}$. Deposits of banking customers have shrunk a thousand times. All these attempts to cut the value of money turned out to be unsuccessful in reducing inflation, and prices continued to soar until hyperinflation occured.

Money is a proof of ownership, that the government owes the owners of money in the form of gold stored in the Central Bank. The amount of money is supported by the amount of gold that can be exchanged at any time. When America no longer supports the money it prints in gold, other countries will imitate it and gradually there will be inflation and a world economic recession. ${ }^{42}$ This is the biggest event in the history of the world economy. Economists have warned about the dangers of such action, but it was the United States that made the eyes of many countries blind to the truth. The voices against the act were weak. ${ }^{43}$ In the Islamic world there are no longer voices of jurists who comment on these events which are very dangerous to the Muslim economy. It means that wealth will be controlled by certain strong parties and will control all sectors of the world economy and are also related to economic problems faced by the world. ${ }^{44}$

It is clear that this digital currency will not be supported by gold, does not go through any administrative processes and does not come from the central bank of any country in the world. This action has paved the way for creating money from something of no value or from something unreal. USD printing is an established

39 Ahamed Kameel Mydin Meera, The Theft of Nations, p.51.

40 A. C. A. Dake, The Sukarno File, 1965-1967: Chronology of a Defeat, Social Sciences in Asia, v. 9 (Leiden ; Boston: Brill, 2006). p.111.

41 Dake.

42 Abdullah Ubaid al-Aun, Tijarah Iliktruniyah Fi Al-Umlat Ad-Dauliyab Wa Abkamuba Fi Fiqh al-Islami (Yordania: Jami'ah al-Urdun, 1986), p. 61.

43 Bashayarah, Hasan Husain, Siyasah Tadakbul ad-Daulah fi Suq as-Sil'ah wa al-Khidmat fi al-Iqtishad al-Ilami (Amman: Dar Imaduddin li an-Nasyr wa Tauzi', 2010).

44 Arthur O’Sullivan et al., Economics: Principles in Action (Needham, Mass.: Prentice Hall, 2003), p.156 
and strong process, therefore it is tradable in other words the United States has created money out of nothing. ${ }^{45}$ The money is no longer supported by gold nor by any other assets. The bond between currency and gold has been stripped since the Bretton Wood agreement was broken. Even the United States was able to create its gold and silver from nothing or worthless without a single country being able to oppose and protest against it. The strength of its currency increases with the increase in military and political power. That way a small elite group can control the world economy from not real money. They exploit the world with power and influence, especially against weak countries. Weak countries always depend on the American dollar, and have abundant natural resources which are then exchanged for worthless papers, because they are no longer supported by gold. ${ }^{46}$

That is the difference between a currency that is backed by gold and silver or other assets of value, and a currency that is enforced by a state that has power in exchange for such assets. The United States government once carried out houseto-house raids by taking the gold they had with printed paper money. Inflation occurs because the printing of too much money compared to the goods that are available. However, if the actual money or money that is supported by assets in the form of gold and silver and other forms circulates well, inflation will not be able to increase significantly. Inflation is the biggest economic problem faced by the world, especially weak countries, even though these weak countries have gold as their main natural resource. However, other symptoms are already visible, such as large-scale gold purchases by China and Russia to support the economies of these two countries. ${ }^{47}$

\section{Countries Supporting Bitcoins}

Bitcoin is still debatable, when digital money has spread to all corners of the world. There are those who allow and who prohibit them, who prohibit them consider this money illegal, do not have a legal law and regulation. It is only used on the internet without any physical form, this money was created during the financial crisis in 2008 as a substitute for official money. This cryptocurrency increased in value, reaching, USD 26,000, or 385 million in September 2018, which in 2012 was only around USD 5-7 per keeping. ${ }^{48}$ Central banks of various countries warn

45 Ahamed Kameel Mydin Meera, The Theft of Nations.

46 Ahamed Kameel Mydin Meera.

47 Lewis E Lehrman, True Gold Standard - A Monetary Reform Plan Without Official Reserve Currencies, 2012. p.141

48 Mohd Ma'Sum Billah, Halal Cryptocurrency Management (Cham: Palgrave Macmillan US, 2019), p.89 
against buying or making transactions with bitcoin. ${ }^{49}$ Given the very large risk to its users and the central banks are trying to protect their consumers. Financial analysts say this ban is related to the future of banking due to the widespread use of bitcoin which endangers the banking sector and the value of the currency in their respective countries. ${ }^{50}$ The exchange rate of bitcoin throughout the year continued to fluctuate, the value decreased and rose significantly. In 2012 the value of bitcoin was only in the range of USD 5-7 per chip. In 2013, the value of bitcoin was in the range of USD10-300. In 2014 the value of bitcoin was recorded at USD700, but at the end of the year it fell to the position of USD 300 per chip. Entering 2015, bitcoin was recorded at USD 200 and at the end of 2015 it was recorded at USD 420 per chip. 2016 bitcoin price of USD 450 per chip and the end of the year USD $950 .{ }^{51}$ Diantara negara yang mendukung Bitcoin adalah, Amerika Serikat, Bitcoin ditumbuhkembangkan di Amerika Serikat. Meski demikian, penggunaan bitcoin di AS belum terlalu banyak jumlahnya yaitu sekitar $25 \%$. One of the countries that support Bitcoin is the United States, Bitcoin was established in the United States. However, the use of bitcoin in the US is not that large, approximately $25 \%$. This use is mostly for online shopping payments. In fact, bitcoin can even be used to pay for tuition fees and other bills. The United States encourages tourists to own Bitcoin and report it if it has a value of more than USD10,000.52

German has admitted that Bitcoin is electronic currency. Therefore, the government can impose profit taxes on companies which use electronic money as a transaction tool in various kinds of activities. ${ }^{53}$ The Realization of Japan has been seen by the number of retailers who carry out their activities by using bitcoin payments. The number of the sellers enforcing the bitcoin is more than 4.500 outlets. The Nikkei run into a surge in transactions after partnering with bitcoin by the end of 2017 .

\section{The Countries Defying Bitcoin}

Although many are interested in investing bitcoin, central banks of the major countries have issued a decision to prohibit the use of digital money or bitcoin, including: ${ }^{54}$

49 zain, "Mining-Trading Cryptocurrency Dalam Hukum IslAM."

50 Moser, Bohme, and Breuker, "An Inquiry into Money Laundering Tools in the Bitcoin Ecosystem."

51 Campbell-Verduyn, Bitcoin and Beyond, p.115

52 Bahits, Ikrar Indama Asbaba Waziran, 69.

53 Muhammad Nizar, "Kontroversi Mata Uang Digital," 2018, p.159.

54 Penguin, Chomping at the Bitcoin The Past, Present and Future of Bitcoin in China. (Penguin Books China, 2014), p.178 
1. China, this country has directed to close the Bitcoin exchange, which causing unrest on conventional stock exchanges. Its value has reached 150 billion USD, which is $23 \%$ of all electronic money in circulation world wide circulation. China is trying to prevent the enormous capital changing into bitcoin flown abroad. After China banned the use of bitcoin and required the use of legal means of payment, the value of bitcoin decreased by $10 \%$.

2. Saudi Arabia, this country announced through the Saudi financial institution "the same" that the institution has taken a decision to prohibit the banks in their country buying Bitcoin. Because bitcoin can not be legalized by the central bank and it is against the policy of the central bank. Bitcoin has been used as a tool for illegal transactions in export and import and it does not obey any tax rules

3. Lebanon, the Central Bank of Lebanon forbids the purchase of bitcoin and the use of it for any payment

4. Iceland, this country has strict rules in capital and investment which is part of a very sensitive monetary policy after the world economic crisis in 2008. This country is trying to control the flow of capital flows in their country. They consider that Bitcoin is incompatible with their banking rules.

5. Vietnam, since Bitcoin was issued, this country through its central bank has banned the use of Bitcoin as a means of transaction or storage. The use of Bitcoin in Vietnam is illegal because it is linked to criminal acts, such as money laundering.

6. Bangladesh, the Central Bank of Bangladesh reveal its concern about the absence of a unified payment system by Bitcoin which would harm the consumers. Under the money control law of 1947 and the money laundering control law of 2012, the use of Bitcoin and other digital money is means to a prison sentence of 12 years. The central bank issued an official statement in September 2016, it is said that any activity involving Bitcoin or any Cryptocurrency would derive the legal sanctions.

7. Bolivia and Kyrgyzstan, the Central Banks of these two countries warn not to engage in any activity involving Bitcoin or counterfeit money.

8. Ecuador and Russia, these two countries indirectly recommend the use of Bitcoin in any form. As in Ecuador, the majority of parliamentarians prohibit the use of Bitcoin. Meanwhile in Russia, this prohibition no longer exists because in this country Bitcoin has legal force. Due to the ban on sites linked to Bitcoin and other digital money, it has been removed. But warnings keep popping up in the Russian mass media which unofficially chanted by economic experts. 


\section{The Position of Money and Country in Islam}

Money in Islam has requirements to fulfill so that it can be used. Each country imposes certain requirements on money circulating in its country and adjusted to the international regulations so that money could be recognized as a means of transaction and exchange of value and goods. Bitcoin is crypto money (cryptocurrency), which has no physical form, just like other digital and electronic money, such as, Ethereum, Ripple, Litecoin, IOTA and others. ${ }^{55}$

All of them are digital money which is not quite different. All of this digital money is decentralized, that enable controlled and managed by the individuals with privacy and confidentiality which is not easy to handled. It is caused the digital money is unofficially assigned to any institution and have no intermediaries such as banks because of not bound to a financial institution, it has neither origin nor actual balances and accounts. ${ }^{56}$ The money is not protected by any financial rules or laws, and is not controlled by any supervisory board. This is one of the reasons for the drastic increase in value and a sudden drop in value. In addition, there is obscurity about who is promoting this digital money. ${ }^{57}$ Therefore, digital money, including Bitcoin, is very vulnerable to changes in value drastically and suddenly. The recognition of Bitcoin as a legal currency has never been officially declared by any country. The sharia standardization (Islamic law) which is mutabar (in accordance in Islamic law) has not been owned by Bitcoin so that it can be held by the state, in other words, in order to be able to be recognized from a certain country.

This is what expressed by fuqaha about the printing money. Thus, ownership or adoption of currency in Islamic law is part of the state's duties. Only the state can issue and regulate currency according to applicable laws. In the nash (the script of the rules) written by the fuqaha, both coins made of gold and silver such as gold dinars and silver dirhams, had intrinsic value. The value attached to the money corresponds to the content it contains, which has a very low rate of decline and increase in value. ${ }^{58}$

Imam Ahmad bin Hanbal said "Money is illegal unless it is done by the official printing with the permission of the sultan. If it is allowed to people print it, they would commit grave crimes." ${ }^{59}$ According to Imam Nawawi, making own

55 Billah, Halal Cryptocurrency Management.

56 Kalle Rosenbaum, Grokeking Bitcoin (Shelter Island, NY: Manning Publications Co, 2019), p.151

57 Billah, Halal Cryptocurrency Management.

58 Ahamed Kameel Mydin Meera, The Theft of Nations. p.115

59 N. Mufid, Lembaga-Lembaga Politik ISlam Menurut Al-Mawardi Dalam Bukunya Al-Ahkam 
money is makhruh (reprehensible) despite of pure gold, because making money is the government's right. ${ }^{60} \mathrm{He}$ also said, "Although the crowd is allowed to make money by using camel leather, until it resembles coins, I still revealed that it is makruh (reprehensible) to be purchased or bartered it with gold and money." 61 Imam Malik's opinion is the rule regarding the status of money in a state. Money must be printed by the state, in any form, whether it is made of gold, camel skin or others have to obtain the legality. The money is distributed by the state and known in various forms, so people could use it staidly because there is a guarantee from the government about the value of the money. Money might be in the form of gold and silver or others which represent it, therefore money have to be exchanged in the equal value, even if in various forms, both old and new it still has the equal value. It is clear that as the basic requirement of money is the confession of the state and it is printed by the state or an institution appointed by the state. Money is a measurement of value, the price of goods, a means of paying debt. All of this is encompassed of the state's law. ${ }^{62}$

If reviewed, Bitcoin or digital money has none of these elements, both legally using it and where it is originated. Bitcoin is unbound to official institutions or intermediaries and have no account or essential balance, especially since the origin of its creation has not been clearly and definitely known. Bitcoin has no aegis of legal protection in its use, so it is vulnerable against the fraud. Even by the drastic fluctuation of the value of Bitcoin instantly, the risk of loss on the part of consumers is higher than gambling which is prohibited in Islamic Sharia. This might take people's rights with vanity, meanwhile at the judgment day the responsibility of how the wealth was obtained and how it was spent would be asked for.

Believers! Do not devour one another's wealth illegally, but rather trade by mutual consent. And do not kill 'each other or' yourselves. Surely Allah is ever Merciful to you. (Q.S an-Nisa: 29)

"the one who deceive us, is not one of us." (HR. Muslim: 101) ${ }^{63}$

Al-Sulthaniyab: Laporan Penelitian (IAIN Sunan Ampel, 1998), p.21

60 an-Nawawi, Syaikhan Khalil Ma'mun, and Ar-Rafi'iy, Abdul Karim bin Muhammad, Raudab Talibin wa Umdah al-Muftin (Beirut: Dar al-Ma'rifah, 2006).

61 Malik bin Anas bin Malik bin Amir al-Asbahi al-Madani, al-Mudawanah, vol. 7 (Beirut - Lebanon: Dar Al-Kotob Al-ilmiyah, 1994), p. 224.

62 Meirison Meirison, "Riba and Justification in Practice in Scholars' Views," TRANSFORMATIF 2, no. 1 (September 20, 2018): 348, https://doi.org/10.23971/tf.v2i1.922.

63 Muslim ibn al-Hajjāj al-Qushayrī et al., Șạih Muslim: English Translation of Sahîh Muslim, 1st ed (Riyadh: Darussalam, 2007), p.283. I 
Ibnu Arabi stated the ignorance is a barrier element of sale-purchase agreed by Muslims, sale-purchase should be clear and measurable, both weight and dimensions, these have to be suitedto their respective conditions. ${ }^{64}$ Bitcoin is out of government's control, whether it is goods or money. It would weaken the state control over the market, both the capital market and goods which causing certain fading. Such as the spread of illegal trade, black market, money laundering and crime have to be eradicated. The Prophet said

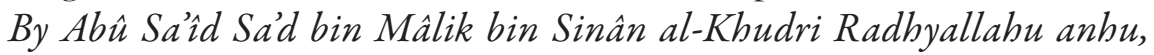
Rasûlullâh Shallallahu 'alaihi wa sallam stated, "There should be neither harming (darar) nor reciprocating harm (dirar)."(H.R Hakim, in Mustadrak, the book of al-Buyu', Sahih Isnad)

Bitcoin brings detriment to the wealth of individuals, society, countries and even the international world.

\section{Intrinsic Value and Equality}

Equality is the foundation of muamalat shariah (the Islamic law of trading) which could be quickly exchanged. As the Prophet Muhammad hadith said: Abu Bakr bin Abu Syaibah had told us, Waki> had told us, sma>il bin Muslim Al> Abdi had told us, Abu Al-Mutawakil An Naji had told us, from Abu Sa>id Al-Khudri, he said: The Messenger of Allah said: Gold is exchanged for gold, silver is exchanged for silver, wheat is exchanged for wheat, barley is exchanged for barley, dates are exchanged for dates, salt is exchanged for salt, it is fine if the amount is the same and immediately handover (cash). Whoever exaggerates or exaggerates, then he has done the practice of usury, either taking or giving. (HR. Muslim No.1584)

It can be seen from the hadith that the exchange of money which has equal value of the goods involving gold which is equal with the production factors, such as wheat, palm and other basic necessities that would make the money stable and unchange drastically in just seconds or hours. Direct exchange is a solid effective wasilah to prevent creating money (creation of money) ${ }^{65}$. The exchange of gold and silver is the basis of the assets considered by Islamic law. Although what exchanged in symbols form is based on the belief that the symbol or representative in the form of bond paper and ownership marks known as paper money/ fiat

64 Ali Salus, Mausu'ah al-Qadhaya al-Fiqhiyah al-Mu'ashirah Wa al-Iqtishad al-Islamiy (IslamKotob, n.d.), p.89,

65 A.M. Māwardī and A.M. Baghdādī, Kitab Abkeam Sultaniyah Wa Wilayah Ad-Diniyah (,(1989, دارلوفاء 181, ) 
money. ${ }^{66}$ Equality is the bulwark against riba' (usury) and direct transactions and exchanges would preclude the creation of money (which is worthless) ${ }^{67}$. Direct exchange will not be created except by using the real property, usury and money creation are the first steps in the destruction of the world economy and cause various problems. It breaks the balance created by Allah S.W.T, who has provided sustenance in the form of gold and silver and which will be exchanged for other forms of value. There is loss of balance and divine justice, which is replaced with injustice committed by forces who actually do not believe in Allah and the rebel against His power.

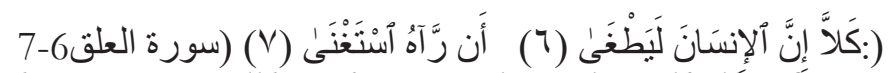

"In fact, the human being oversteps all bounds. Because he sees himself self-sufficient." (QS. Al-Alaq: 6-7)

Allah has created money but humans created fake money which is not backed by gold. By using various skills, money could be created such as electronic money which is created monopolically. Money might generate large amounts of wealth but it has no intrinsic value. Therefore, money can be played by the price and controlled as needed. Like paper money, the electronic money can be controlled so as not to undergo a drastic deterioration or changing with a high and fast frequency. it is such gambling prohibited by Islamic law. Later, the legal basis was created and the ulema (Islamic scholars) scattered around the world allowed it without considering the legality of this electronic money further. Another opinion stated that it is permissible to use electronic money in an emergency. the same as the position of paper money after it was unbond with gold.

If Muslim countries desired to get the independence and economic freedom, and spread justice on earth, they should sell-purcase for something which is valueable like gold and silver. At least transactions are carried out by the backing of gold and silver or with movable and immovable assets.

\section{The Legal of Electronic Money Backed by Gold}

Heretofore, electronic money has not been backed by gold, it is just promised to be exchanged through its representatives for concrete objects. It is just a kind of

66 Ḥ.Ṣ. Inānī and Mahad al-Dawlī lil-Bunūk wa-al-Iqtișād al-Islāmī Qism al-Shar ī, Mukjižah Al-Islam Fi Mawrif Min Ar-Riba, Majmu'al-Bubuts al-Mutakamilah (Virginia: IMa'had ad-Duali lil Bunuk al-Islami Qism as-Syar'iy, 1983), 221,

67 Desmadi Saharuddin et al., "Capitulation and Siyasah Syar'iyah Al-Maliyah Impact on Economic Stability of the 18th \& 19th Ottoman Turks," QIJIS (Qudus International Journal of Islamic Studies) 7 , no. 2 (January 6, 2020): 329, https://doi.org/10.21043/qiijis.v7i2.4847. 
normative promise that is suggestive or moral in nature, without any consequences for breaking the promise. It is protected neither by constitutions nor by any laws, only limited trust which is unbound and the no sanctions for the violators. ${ }^{68}$

The price of electronic money should refer to the price of gold so that it could get a justification that this electronic money is backed by gold. If the fluctuational price is much different from the price of gold, it cannot be used as a transaction means. Due to changes in the price of gold is unable increase and decrease drastically and suddenly. If the value of this money changes drastically in a short time, definitely the electronic money is not backed by the gold. Therefore, using digital money as a transaction means is haram (prohibited) because its characteristics are closely similar to gambling and sale-purchase of gharar (uncertainty) ${ }^{69}$ forbidden by the Qur'an and al-Hadith. If the digital money or bitcoin is bound by gold support, then the money is not independent money that is free to enter and exit between countries and even between continents without any obstacles. The money is proof of the bond which would be exchanged for gold one day, obeying to the rules and laws of currency exchange. ${ }^{70}$

\section{The Legal of Electronic Money Backed by Other Valuable Wares}

It is inconceivable that this e-money is backed by gold, although recently issued that a Singaporean company will create e-money that conforms to Islamic law and its printing is backed with gold. It can be seen that the existing electronic money could be exchanged for gold only in terms of moral promises or has permanent legal consequences and recognized by various countries ${ }^{71}$. On the other side, the value must be in accordance with the value of gold so that the justification of this gold support can be seen and measured. If this electronic money has been backed by gold, then it has the same properties as gold, which has unchangeable value drastically and quickly. If the electronic money changes in a short time with a significant decrease and increase, then the electronic money is not backed by gold. Because gold will not be possible to undergo a drastic price changing in a short time. A drastic change in a short period of time in sell-purchase transactions is the same as gambling which is prohibited by Islamic law. ${ }^{72}$

68 Ubaid al-Aun, Tijarah Iliktruniyah Fi Al-Umlat Ad-Dauliyah Wa Abkamuba Fi Figh al-Islami, 98.

69 Jalud al-Jami'ah Sa'd Anzi and Ajil Nasymi, Bitcoin wa Umlah Ilitroniyahfi al-Fiqh al-Islami, 1st ed. (Kuwait: Muasasah al-Khairiyah, 2020), 23.

70 Benjamin J Cohen, The Future of Money (FinanzBuch Verlag.), http://liverpool.idm.oclc.org/ login?url=https: //www.jstor.org/stable/10.2307/j.ctv39x5cd.

71 Franco, Understanding Bitcoin.

72 Jalud al-Jami'ah Sa'd Anzi and Ajil Nasymi, Bitcoin wa Umlah Ilitroniyabfi al-Figh al-Islami, 1st ed. (Kuwait: Muasasah al-Khairiyah, 2020), p.35. 
If the electronic money is supported by movable or immovable assets, such as land, buildings and other assets, so it is a bonded bond (ownership bond) not as money. If it has been treated and used as money, it should be reviewed, so that it would exclude of the element of gambling.

Bitcoin or cryptocurrency is not money but kind of merchandise. However, the source of this item is unknown and he has no guarantee. The Bitcoin could be used as a medium of robbing, cheating, multiplying money, therefore, it is prohibited for trading, since the sources is unknown. However, the strong prejudice of the Bitcoin's sources is not far from the big capitalist countries, especially the United States, or private institutions which are bound to these big countries. ${ }^{73}$ They have an unkind goal, consisting of big companies, to play with the economies of resource-rich countries and third world countries. A big question, why is the source of Bitcoin is still kept secret. Goods whose origins are not clear there is no guarantee whatsoever which is very vulnerable to the deception which is dominated by the imperialist capitalist countries, especially the United States of America to exploit the wealth owned by the world's population. Therefore, the money is unable to be traded based on syara' which prohibits the sale purchase of unknown goods:

Imam Muslim rahimahullah narrated from Abu Hurairah Radhiyallahu anhu, he said:

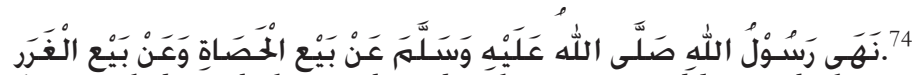

"Rasulullah S.A.W prohibitted the trading by throwing peebles and gharar trading."(H.R Muslim)

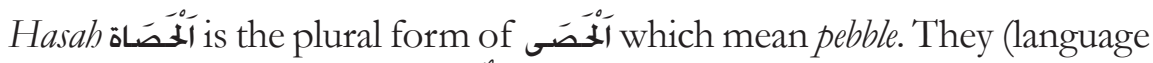
expert) said, "that the sentence بَيْعُ الْحَصَصَاة is included in the category of idhafah (leaning) mashdar (basic word) to its kind. "The meaning of sell trading is by throwing pebbles, that is, a seller says to the buyer," Throw this pebble, wherever this pebble falls, that is the final limit of the land that you buy." Buying and selling like this is haraam (prohibitted) and includes sell-purchase of Jabiliyyah (the ignorance of pre-islamic period). And according to them (the islamic scholars) buying and selling in this way does not only apply to goods in the form of land, but can also all items that can be thrown with gravel, whether in the form of buying and selling goats, clothes, food or anything else

73 Abdullah Ubaid al-Aun, Tijarah Iliketruniyah Fi Al-Umlat Ad-Dauliyah Wa Abkamuba Fi Fiqh al-Islami (Yordania: Jami’ah al-Urdun, 1986), p.21.

74 Muslim ibn al-Hajajāj al-Qushayrī et al., Sahịh Muslim: English Translation of Sabîh Muslim, 1st ed (Riyadh: Darussalam, 2007), p. 98. 
75. This prohibition is caused by an element of damage, namely the damage to sell-purchase (sell-purchase of vanities). this is due to two things, it is jahalah (unclear goods), and the element of fraud.

Al-Mubaqalah is taken from the word الحَحَقْل which means field, where agricultural products are still in the fields. The purpose of muhaqalah trading is selling ripe grains (such as wheat, rice, etc.) which are still on the stalks with similar grains.

In buying and selling this model, two things that are forbidden are collected, they are: ${ }^{76}$

a. The unclearness of the content of the goods traded.

b. There is an element of riba' (usury) because it is not certain that there are similarities between the two goods traded. Whereas the syar'i (Islamic law) stipulation in this case is, "That the uncertainty of the similarity (between two items traded) is the same as measured for sure the existence of tafadhul (exaggerating one of the items being exchanged) in legal matters."

This ambiguity is because the grains on the stalks are not known for their exact weight (weight) and the good and bad of the goods are not known. There is an element of riba' (usury) here because trading grain with similar seeds without a known syar'i (Islamic law) measure will cause confusion in something.

Imam al-Bukhari rahimahullah narrated from Anas bin Malik anhu Radhiyallahu, he said:

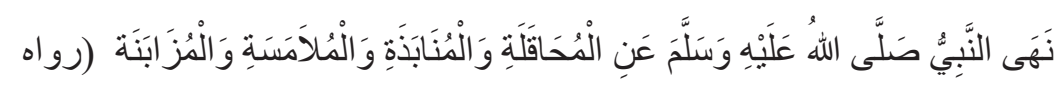

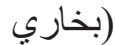

The Prophet sallallaahu <S.A.W probibited the trading by means of muhaqalah, munabadzah, mulamasah, and muzabanah ${ }^{77}$."

The existence of Bitcoin as a virtual currency is considered valid, legal, or permissible under several conditions, such it is recognized by the state. This is because the rights and obligations to take care of iqtishadiyab including the issuance of new currencies are the authority of the state. It is based on the plan of the caliph Umar bin Khattab (head of government) to make a new type of currency from camel leather. ${ }^{78}$ However, Bitcoin must be backed by gold which has binding legal

75 al-Sayyid Sabiq, Fiqh Us-Sunnah (Indianapolis, Ind., USA: American Trust Publications, 1985), p.181.

76 Muhammad Sa'id Ramadhan al-Buthi, Qadhaya Fiqbiyah Mu'ashirah (Dar al-Farabi lil Ma'arif, 2001), p.111

77 Ibnu Hazar al-Atsqalani, Fatbul Bari fi Syarh Sabih al-Bukhari, vol. 12, 3, No. 2057 vols., 1986.

78 Ausop and Aulia, "TEKNOLOGI CRYPTOCURRENCY BITCOIN UNTUK INVESTASI DAN TRANSAKSI BISNIS MENURUT SYARIAT ISLAM.” 
consequences. In essence Bitcoin cannot fulfill these criteria because the Bitcoin would be the same as fiat money (a government-issued currency that isn't backed by $t$ a commodity such as gold) which no longer has a distinction from money circulating as if Bitcoin is used for different purposes from fiat money and other valuable assets.

\section{Conclusion}

Bitcoin is a currency which has no physical form used over the internet, it is stored in an electronic wallet on the hard drive of each computer using special software. Money will move directly without any taxes, without going through any bank or intermediary This money can be used to buy anything as currency in circulation. Even though at the time of Umar bin Khatab, he indicated that money was allowed to be exchanged for camel skins as fiat money became qiyas for those who allowed digital money, Bitcoin, and other Cryptocurrencies but predictions about the harm that money would cause could make it prohibited from being your muamalah medium in Islam based on Sad Zariah (closing the path to badness) although basically the act is allowed but under certain conditions it might cause harm. It is also supported by the principle of fiqh jalb al-masalih wa dar'u al-mafasid which means bringing benefit and rejecting the harm. it stops fighting between the parties who allow and prohibit it. Due to the argument that was taken as the basis for fiat money regarding the attitude of Umar bin Khatab R.A who allowed money made of camel skin. Which means the money can be in any form even though in computer software which taking weeks to play games and then generates Bitcoin which is increasingly experiencing higher levels of difficulty can also bring harm both physically and spirittually.

Bitcoin and other digital money unsuit the provisions of the Islamic Shariah, which means that money must be originated by the state, and Get an oversight in a standard of value guaranteed by the state in transactions. The money must also be backed by gold, meanwhile money is only limited to numbers bonded by the government that warranting the money can be exchanged for gold.

Bitcoin is an unknown and unsecured commodity that is vulnerable to fraud, and various formsof crime, such as smuggling, money laundering and others. Bitcoin is not far away from big countries like the United States to exploit the natural resources of other countries. Therefore it is recommended not to buy it with syar' iy (Islamic law) arguments which prohibit buying and selling goods that are unclear and fraught with deception. 


\section{References}

Ahamed Kameel Mydin Meera. The Theft of Nations: Returning to Gold. Subang Jaya, Selangor Darul Ehsan, Malaysia: Pelanduk Publications, 2004.

Ammous, Saifedean. The Bitcoin Standard: The Decentralized Alternative to Central Banking. Hoboken, New Jersey: Wiley, 2018.

an-Nawawi, Syaikhan Khalil Ma'mun, and Ar-Rafi'iy, Abdul Karim bin Muhammad. Raudah Talibin wa Umdah al-Muftin. Beirut: Dar al-Ma'rifah, 2006.

Anzi, Jalud al-Jami'ah Sa'd, and Ajil Nasymi. Bitcoin wa Umlah Ilitroniyahfi al-Fiqh al-Islami. 1st ed. Kuwait: Muasasah al-Khairiyah, 2020.

Astrid Dwijayanti, Astrid Dwijayanti. "Pasar Mata Uang Kripto Alami Tren Penurunan, Berbeda Dengan Indonesia Yang Pertahankan Stabilitas Harganya." Commerce. Finroll.Com (blog), December 3, 2018.

Atsqalani, Ibnu Hazar al-. Fathul Bari fi Syarh Sahih al-Bukhari. Vol. 12. 3, No. 2057 vols., 1986.

Ausop, Asep Zaenal, and Elsa Silvia Nur Aulia. "Teknologi Cryptocurrency Bitcoin Untuk Investasi Dan Transaksi Bisnis Menurut Syariat Islam.” Jurnal Sosioteknologi 17, no. Vol.17, No1, April 2018 (April 2018): 19. http://dx.doi. org/10.5614\%2Fsostek.itbj.2018.17.1.8.

Bahits, Muhammad. Ikrar Indama Asbaha Waziran. Dar Sibawaihi Li Taba' wa Nasyr, 2018. https://books.google.co.id/books?id=tDxvDwAAQBAJ.

Bashayarah, Hasan Husain. Siyasah Tadakhul ad-Daulah fi Suq as-Sil'ah wa al-Khidmat fi al-Iqtishad al-Ilami. Amman: Dar Imaduddin li an-Nasyr wa Tauzi', 2010.

Beaugrand, Philippe. Henry Thornton, Un Précurseur de J.M. Keynes. Travaux et Recherches de l'Université de Droit, d'économie et de Sciences Sociales de Paris, no 9-11. Paris: Presses universitaires de France, 1981.

Billah, Mohd Ma'Sum. Halal Cryptocurrency Management. Cham: Palgrave Macmillan US, 2019. https://public.ebookcentral.proquest.com/choice/ publicfullrecord.aspx?p $=5795960$.

Buthi, Muhammad Sa’id Ramadhan al-.Qadhaya Fiqhiyah Mu'ashirah. Dar al-Farabi lil Ma'arif, 2001. https:/ / books.google.co.id/books?id=ghiOxgEACAAJ.

Campbell-Verduyn, Malcolm, ed. Bitcoin and beyond: Cryptocurrencies, Blockechains and Global Governance. RIPE Series in Global Political Economy. London ; New York: Routledge, Taylor \& Francis Group, 2018.

Cohen, Benjamin J. The Future of Money. FinanzBuch Verlag. http:// liverpool.idm.oclc.org/login?url=https://www.jstor.org/stable/10.2307/j. 
ctv39x5cd.

Conradie, Willem, and Valentin Goranko. Logic and Discrete Mathematics: A Concise Introduction. Chichester, West Sussex, UK ; Hoboken, NJ, USA: John Wiley \& Sons Inc, 2015.

Dake, A. C. A. The Sukarno File, 1965-1967: Chronology of a Defeat. Social Sciences in Asia, v. 9. Leiden; Boston: Brill, 2006.

Dr. S. T. Bhosale, Dr. S. T. Bhosale. "Blockchain In Highereducation Institutions." International Journal of Advance and Innovative Research 6, no. 3 (September 2019): 124-27.

Fitriani, Revi. "Pemikiran Ekonomi Islam Ibnu Khaldun Islamic Economic Thought Of Ibnu Khaldun,” no. 2 (2019): 15.

Franco, Pedro. Understanding Bitcoin: Cryptography, Engineering and Economics. Wiley Finance Series. Chichester, West Sussex, United Kingdom: Wiley, 2015.

Inānī, H.., and Mahad al-Dawlī lil-Bunūk wa-al-Iqtiād al-Islāmī Qism alSharī. Mukjizah Al-Islam Fi Mawqif Min Ar-Riba, Majmu'al-Bubuts al-Mutakamilah. Virginia: 'Ma'had ad-Duali lil Bunuk al-Islami Qism as-Syar'iy, 1983. https:/ / books.google.co.id/books?id=SMJHAAAAYAAJ.

Irwin, Douglas A. "The Nixon Shock after Forty Years: The Import Surcharge Revisited.” World Trade Review 12, no. 1 (January 2013): 29-56. https:// doi.org/10.1017/S1474745612000444.

Islamic Business School, College of Business, Universiti Utara Malaysia, Malaysia, Nashirah Abu Bakar, Sofian Rosbi, School of Mechatronic Engineering, Universiti Malaysia Perlis, Malaysia, Kiyotaka Uzaki, and Department of Business Studies, Oita University, Japan. "Cryptocurrency Framework Diagnostics from Islamic Finance Perspective: A New Insight of Bitcoin System Transaction." International Journal Of Management Science And Business Administration 4, no. 1 (2017): 19-28. https://doi.org/10.18775/ijmsba.1849-5664-5419.2014.41.1003.

Lehrman, Lewis E. True Gold Standard - A Monetary Reform Plan Without Official Reserve Currencies, 2012.

Majid Salim Drausyah. Saddu Zarai' fi Jaraim al-Qatl: Dirasah Muqaranah, 2008.

Malik bin Anas bin Malik bin Amir al-Asbahi al-Madani. al-Mudawanah. Vol. 7.3 vols. Beirut - Lebanon: Dar Al-Kotob Al-ilmiyah, 1994.

Māwardī, A.M., and A.M. Baghdādī. Kitab Abkam Sultaniyah Wa Wilayah Ad-Diniyah. 1919 19. دار الوفاء 1 . https://books.google.co.id/books?id=sQy9xgEACAAJ.

Māwardī, Alī ibn Muḥammad, and Aḥmad Mubārak Baghdādī. Kitāb Al- 
Aḥkàm al-Sulțānìah Wa-al-Wilāyat al-Diñyah. Al-Ṭabah 1. al-Manūrah [Egypt] : al-Kuwayt: Dār al-Wafā ; Maktabat Dār Ibn Quțaybah, 1989.

Meirison, Meirison. "Riba and Justification in Practice in Scholars' Views." TRANSFORMATIF 2, no. 1 (September 20, 2018): 348. https://doi. org/10.23971/tf.v2i1.922.

Moser, Malte, Rainer Bohme, and Dominic Breuker. "An Inquiry into Money Laundering Tools in the Bitcoin Ecosystem." In 2013 APWG ECrime Researchers Summit, 1-14. San Francisco, CA, USA: IEEE, 2013. https://doi. org/10.1109/eCRS.2013.6805780.

Mufid, N. Lembaga-Lembaga Politik. ISlam Menurut Al-Mawardi Dalam Bukunya Al-Abkam Al-Sulthaniyah: Laporan Penelitian. IAIN Sunan Ampel, 1998. https:// books.google.co.id/books?id=kZCMGwAACAAJ.

Muslim ibn al-Hajjāj al-Qushayrī, Abū Țāhir Zubayr Alī Zāi, Nasiruddin Khattab, Huda Khattab, and Abū Khalīl. aḥh Muslim: English Translation of Sabîh Muslim. 1st ed. Riyadh: Darussalam, 2007.

Nizar, Muhammad. "Kontroversi Mata Uang Digital," 159-81, 2018.

O'Sullivan, Arthur, Steven M Sheffrin, Inc Prentice-Hall, and Wall Street Journal (Firm). Economics: Principles in Action. Needham, Mass.: Prentice Hall, 2003.

Penguin. Chomping at the Bitcoin The Past, Present and Future of Bitcoin in China. Penguin Books China, 2014.

Rau, Dana Meachen. The History of Money. Money and Banks. Milwaukee, WI: Weekly Reader Early Learning Library, 2006.

Rosen, Kenneth H., Douglas R. Shier, and Wayne Goddard, eds. Handbook of Discrete and Combinatorial Mathematics. Second edition. Boca Raton: CRC Press, Taylor \& Francis Group, 2018.

Rosenbaum, Kalle. Grokking Bitcoin. Shelter Island, NY: Manning Publications Co, 2019.

Sa'ad al-Syatari, Sa'ad al-Syatari. Al-Takhrij Baina al-Ushul Wa al-Furu. Kairo: Dar al-Hadits, 1989.

Sabiq, al-Sayyid. Fiqh Us-Sunnah. Indianapolis, Ind., USA: American Trust Publications, 1985.

Saharuddin, Desmadi, Meirison Meirison, Inayatul Chusna, and Ade Sofyan Mulazid. "Capitulation and Siyasah Syar'iyah Al-Maliyah Impact on Economic Stability of the 18th \& 19th Ottoman Turks." QIJIS (Qudus International Journal of Islamic Studies) 7, no. 2 (January 6, 2020): 329. https://doi.org/10.21043/ qiijis.v7i2.4847. 
Salus, Ali. Mausu'ah al-Qadhaya al-Fiqhiyah al-Mu'ashirah Wa al-Iqtishad al-Islamiy. IslamKotob, n.d. https://books.google.co.id/books?id=zSPDKhlKVC4C.

Syamsuddin, Ahmad, Ahmad Shams al-Din, al-Qāsim ibn Abd Allāh Ibn Quṭlūbughā, and Al̄̄ ibn Abī Bakr Marghīnānī. Nasab Ar-Rayah : Takhrij Ahadits al-Hidayah. Bayrut: Dar al-Kutub al-'Ilmiyah, 2002.

Teichova, Alice, G Kurgan-van Hentenryk, and Dieter Ziegler. Banking, Trade and Industry: Europe, America and Asia from the Thirteenth to the Twentieth Century. Cambridge: Cambridge University Press, 2011.

Ubaid al-Aun, Abdullah. Tijarah Iliketruniyah Fi Al-Umlat Ad-Dauliyah Wa Abkamuba Fi Fiqh al-Islami. Yordania: Jami'ah al-Urdun, 1986.

Wewege, Luigi. The Digital Banking Revolution: How Financial Technology Companies Are Rapidly Transforming Retail Banking. Cork: BookBaby, 2017. http:/ / public.eblib.com/choice/publicfullrecord.aspx?p $=4801300$.

Yazbak, Mahmud. Haifa in the Late Ottoman Period, 1864-1914 : A Muslim Town in Transition. First. Vol. 2. 1 vols. Leiden, Netherlands: Brill, 1998.

Yazdani-Chamzini, Abdolreza, Siamak Haji Yakhchali, Diana Volungevičienè, and Edmundas Kazimieras Zavadskas. "Forecasting Gold Price Changes By Using Adaptive Network Fuzzy Inference System." Journal of Business Economics and Management 13, no. 5 (October 4, 2012): 994-1010. https://doi.org/10.38 46/16111699.2012.683808.

Yingjie Zhao. "Cryptocurrency Brings New Battles into the Currency Market,” 2015. https://doi.org/10.2313/net-2015-03-1_13.

Zain, Muhammad Fuad. "Mining-Trading Cryptocurrency Dalam Hukum Islam." Al-Manahij: Jurnal Kajian Hukum Islam 12, no. 1 (June 22, 2018): 119-32. https://doi.org/10.24090/mnh.v12i1.1303.

Zubaidi, Ibrahim Bassam, and Adam Abdullah. "Developing a Digital Currency from an Islamic Perspective: Case of Blockchain Technology." International Business Research 10, no. 11 (September 29, 2017): 79. https://doi. org/10.5539/ibr.v10n11p79. 